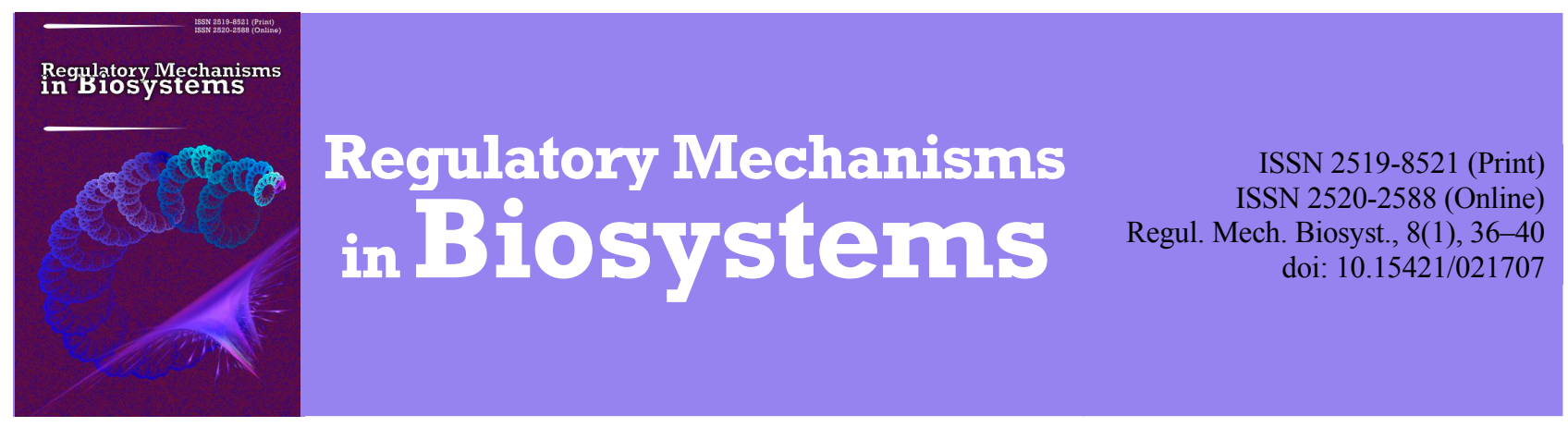

\title{
Changes in the viability of Strongyloides ransomi larvae (Nematoda, Rhabditida) under the influence of synthetic flavourings
}

\author{
A. A. Boyko*, V. V. Brygadyrenko** \\ *Dnipropetrovsk State Agrarian-Economic University, Dnipro, Ukraine \\ **Oles Honchar Dnipropetrovsk National University, Dnipro, Ukraine
}

Article info

Received 11.12.2016

Received in revised form 14.01.2017

Accepted 19.01.2017

Dnipropetrovsk State

Agrarian-Economic University,

Voroshilov Str., 25 ,

Dnipro, 49027, Ukraine

Tel.: + 38-097-296-42-10

E-mail:

boikoalexandra1982@gmail.com

Oles Honchar Dnipropetrovsk National University,

Gagarin Ave., 72 ,

Dnipro, 49010, Ukraine

Tel.: +38-050-93-90-788

E-mail:brigad@ua.fm
Boyko, A. A., \& Brygadyrenko, V. V. (2017). Changes in the viability of Strongyloides ransomi larvae (Nematoda, Rhabditida) under the influence of synthetic flavourings. Regulatory Mechanisms in Biosystems, 8(1), 36-40. doi: $10.15421 / 021707$

One of the most common nematodes of pigs globally is Strongyloides ransomi Schwartz and Alicata 1930. It usually causes aggravation of physiological indicators of its hosts and damage to their immune system. Also it is a good modelling object for the evaluation of the antiparasitic activity of new antihelminthic drugs. We conducted laboratory experiments to assess the effect of flavouring additives with flower odour (benzaldehyde, citral, D-limonene and $\beta$-ionone) upon the viability of $S$. ransomi larvae. The mortality rate was calculated for 24 hours exposure at four concentrations of each substance $(10,1,0.1$ и $0.01 \mathrm{~g} / \mathrm{l})$ with eight replications. The lowest $\mathrm{LD}_{50}$ values were obtained for citral $(97 \mathrm{mg} / \mathrm{l})$ and benzaldehyde $(142 \mathrm{mg} / \mathrm{l})$. These substances are recommended for further evaluation of their antihelminthic effect in experiments using laboratory animals. Unlike other substances, the effect of $\beta$-ionone and D-limonene even at a concentration of $10 \mathrm{~g} / \mathrm{l}$ after 24 hours caused the death of $<50 \%$ of $S$. ransomi larvae. The study of flavouring additives with flowery odour, which are permitted to be used in food for humans and also to be used in cosmetics, is a promising field for research aimed at the development of new antiparasitic drugs.

Keywords: nematodes; antiparasitic activity; flavouring agents; benzaldehyde; citral; D-limonene; $\beta$-ionone

\section{Introduction}

Helminthiasis causes significant economic damage to animal husbandry (Faye et al., 2003; Veneziano et al., 2004; Charlier et al., 2007; Cringoli, 2008; Yamov and Antropov, 2008; Ponomar et al., 2014a, b; Boyko et al., 2016). Pig farming is one of the most common sources of meat products. Among the parasites of pigs, the most common are nematodes, including strongyloidiasis agents (Knecht et al., 2011; Eysker et al., 2011; Samsonovich, 2012a; Maslova et al., 2015). Parasitisation by Strongyloides ransomi (Schwartz and Alicata, 1930) causes loss of concentration of albuminous and albumin fractions in the blood of piglets, loss of erythrocytes, hemoglobin, albumin, phagocytic and lysozyme activity and immune reaction (Samsonovich, 2012b).

Therefore determining the viability of helminths is significant for controlling their population, both in the host, and in the environment. Nowadays, synthetic antiparasitic drugs (Ponomar et al., 2013) are used and experiments of identifying the antihelminthic properties of plants are being conducted (Rahmann and Seip, 2006; Burke et al., 2009; Lu et al., 2010).

To fight pathogenic organisms, microbiologists and virusologists are researching the effect of flavouring agents in food production (Chiang et al., 2005; Sato et al., 2006; Somolinos et al., 2008; Si et al., 2009; Belletti et al., 2010). Because pigs consume food not only of vegetable origin, but also of animal origin, their diet can include synthetic flavouring agents from the diet of humans. Therefore the objective of this research is to define the effect of flavouring agents upon the level of viability of $S$. ransomi larvae (Rhabditida, Strongyloididae).

\section{Materials and methods}

The faeces of pigs were studied to find $S$. ransomi larvae using the Baermann test (Zajac et al., 2011). The material was collected in the summer period in Dnipropetrovsk district, and then transferred to the laboratory in plastic containers at a temperature of $22-24{ }^{\circ} \mathrm{C}$. $S$. ransomi culture is represented by larval stages of freely moving and parasitic forms (Van Wyk and Mayhew, 2013).

Larvae of first and second stage (freely moving) have a rhabditelike oesophagus with two bulbuses. Their intestinal cells are not distinguishable. The parasitic form (third stage) is distinguished by a filariform oesophagus with no extensions; the intestine does not have cells which can be clearly distinguished through an optical microscope (Fig. 1).

After cultivation, the liquid with the larvae was put in test tubes $(10 \mathrm{ml})$ by $4 \mathrm{ml}$ and was centrifuged for four minutes at 1500 revolutions a minute. $1 \mathrm{ml}$ of sediments with larvae was evenly weighed and put in $0.1 \mathrm{ml}$ portions in plastic containers with a capacity of $1.5 \mathrm{ml}$. After that, $1 \mathrm{ml}$ of the substance under research was added to the larval culture (20-40 ind.), which then was kept for 24 hours at a temperature of $22-24{ }^{\circ} \mathrm{C}$. Four concentrations $(10,1,0.1$ и $0.01 \mathrm{~g} / \mathrm{l})$ of each of the flavouring agents were used in the experiments (Table 1), with eight replications.

\section{Results}

The flavouring agents citral, benzaldehyde exhibited the strongest effect on the viability of $S$. ramsomi larvae (Table 2 ). 
Table 1

Properties and usage of flavouring agents* which were used for establishing the viability level of $S$. ransomi larvae

\begin{tabular}{|c|c|c|c|c|c|c|}
\hline \multirow{2}{*}{$\begin{array}{c}\text { Name } \\
\text { of the substance }\end{array}$} & \multirow{2}{*}{$\begin{array}{l}\text { Chemical } \\
\text { formula }\end{array}$} & \multirow{2}{*}{$\begin{array}{c}\text { Structural } \\
\text { formula }\end{array}$} & \multirow{2}{*}{ Properties } & \multirow{2}{*}{ Content } & \multicolumn{2}{|r|}{ Usage } \\
\hline & & & & & in food industry & in medicine \\
\hline Benzaldehyde & $\mathrm{C}_{6} \mathrm{H}_{5} \mathrm{CHO}$ & & $\begin{array}{l}\text { colourless liquid with } \\
\text { odour of bitter } \\
\text { almond or of apple } \\
\text { pips }\end{array}$ & $\begin{array}{l}\text { cores of kernels of bitter } \\
\text { almond, apricot kernels, stones } \\
\text { of peaches, cherries, black } \\
\text { cherries and other stone fruits, } \\
\text { leaves of bird cherry tree, pulp } \\
\text { of oyster mushroom } \\
\text { (Pleurotus ostreatus) }\end{array}$ & as food additive & no data concerning usage \\
\hline $\begin{array}{c}\text { D-limonene } \\
\text { (1-methyl-4- } \\
\text { isopropenylcyclohexene } \\
-1)\end{array}$ & $\mathrm{C}_{10} \mathrm{H}_{16}$ & & $\begin{array}{l}\text { colourless liquid with } \\
\text { odour of citrus }\end{array}$ & $\begin{array}{l}\text { many essential oils, } \\
\text { including citrus }\end{array}$ & as food additive & no data concerning usage \\
\hline $\begin{array}{c}\text { Citral } \\
\text { (3,7- dimethyl -2,6- } \\
\text { octadienal) }\end{array}$ & $\mathrm{C}_{10} \mathrm{H}_{16} \mathrm{O}$ & & $\begin{array}{l}\text { viscous colourless or } \\
\text { bright-yellow fluid } \\
\text { with odour of lemon }\end{array}$ & $\begin{array}{l}\text { essential oil of lemon grass } \\
\text { (citronella), oil of cubeb, lemon } \\
\text { essential oil, eucalyptus and } \\
\text { some other essential oils }\end{array}$ & as food additive & $\begin{array}{l}\text { antiseptics } \\
\text { anti-inflammatory agent, } \\
\text { used to relieve } \\
\text { intracranial hypertension }\end{array}$ \\
\hline $\begin{array}{l}\text { Beta-ionone }((3 \mathrm{E})-4- \\
\text { (2,6,6-trimethylcyclohex } \\
\text {-1-enyl)but-3-en-2-one) }\end{array}$ & $\mathrm{C}_{13} \mathrm{H}_{20} \mathrm{O}$ & $\beta$ & $\begin{array}{l}\text { has a pleasant } \\
\text { flower odour }\end{array}$ & some essential oils & as food additive & no data concerning usage \\
\hline
\end{tabular}

Note: * - Official Journal of the European Union, L 354/46 (2008), Sun (2007), Smirnov (2008).

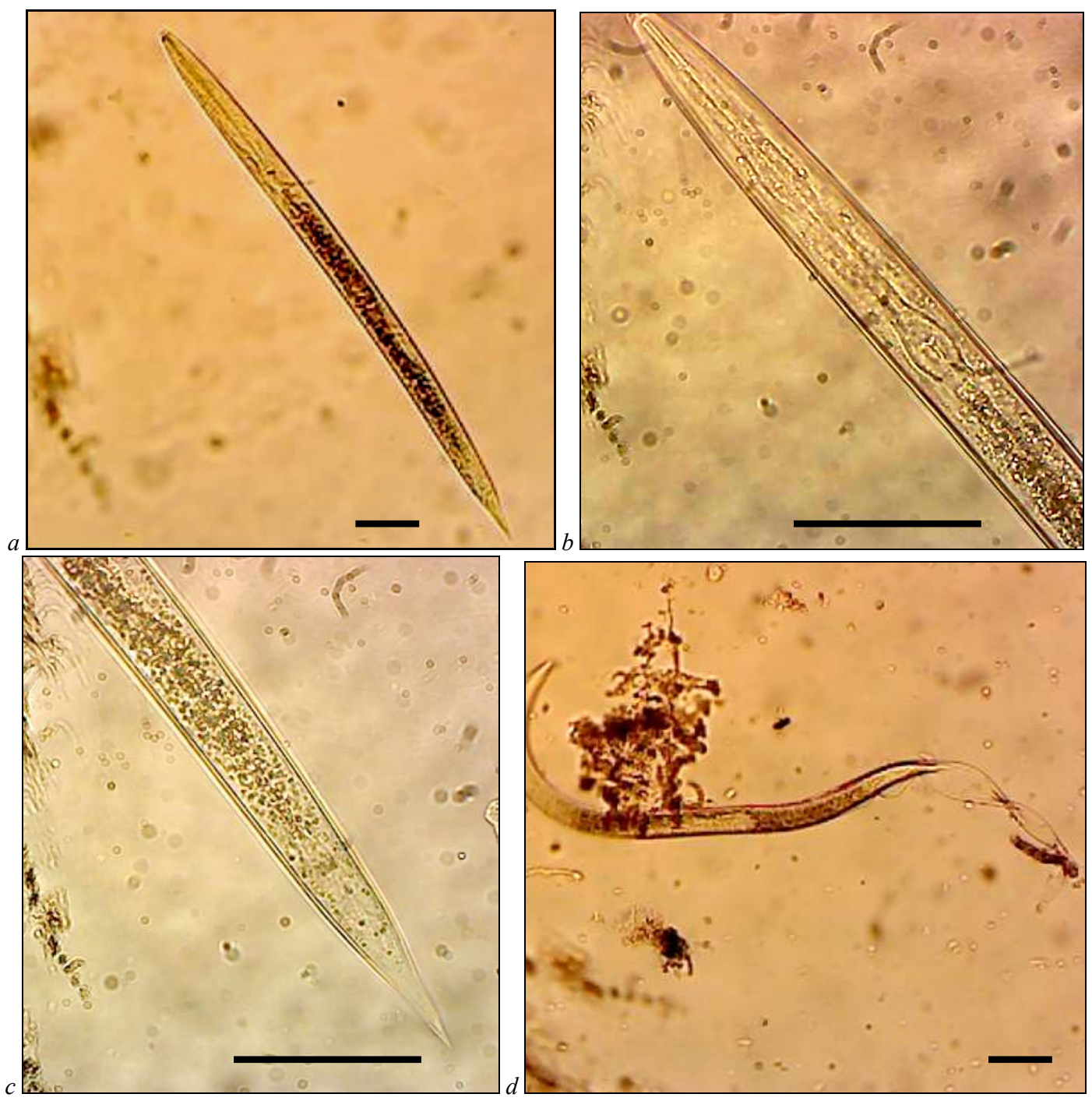

Fig. 1. S. ransomi larvae: $a$ - noninvasional stage, $b$ - filariform oesophagus, $c$-caudal end, $d$ - outlet from the cuticle: length of black bar $-50 \mu \mathrm{m}$ 
Table 2

$\mathrm{LD}_{50}(\mathrm{x} \pm \mathrm{SD})$ for $S$. ransomi larvae in laboratory experiment

\begin{tabular}{lc}
\hline \multicolumn{1}{c}{ Название вещества } & LD $_{50, \mathrm{Mг} / л}$ \\
\hline Benzaldehyde & $142 \pm 64$ \\
D-limonene & - \\
Citral & $97 \pm 36$ \\
Beta-ionone & - \\
\hline
\end{tabular}

Note: $\langle-\rangle-$ the experiment did not achieve death of $50 \%$ larvae (needed concentration of more than $10 \mathrm{~g} / \mathrm{l})$.

D-limonene and beta-ionone at the studied concentrations (less than $10 \mathrm{~g} / \mathrm{m}$ ) did not affect the viability of $S$. ransomi larvae signifycantly, which shows that they are not useful as nematocidal medicines. The maximum effect upon the nematodes at $\mathrm{LD}_{90}$ (Fig. $2 a, c$ ) was shown by benzaldehyde at $685 \mathrm{mg} / \mathrm{l}$. In this case, the larvae of the $100 \%$ nematodes studied perished in benzaldehyde solutions with a concentration of 1 and $10 \mathrm{~g} / \mathrm{l}$. Thus, this substance can be used for further development of veterinary drugs with anthelmintic effect.

\section{Discussion}

Nowadays research is being conducted on the extent of effect of flavouring agents on the viability of agents of infection. Chiang et al. (2005) discovered the antiviral function of a broad spectrum of apigenin, linalool and ursolic acid. These substances are extracted from basil, which is familiar in Chinese medicine as a medicinal plant. The antimicrobial function of these compounds such as linalool and citral is well attested. They are capable of inhibiting the growth of pathogenic microorganisms (Sato et al., 2006; Somolinos
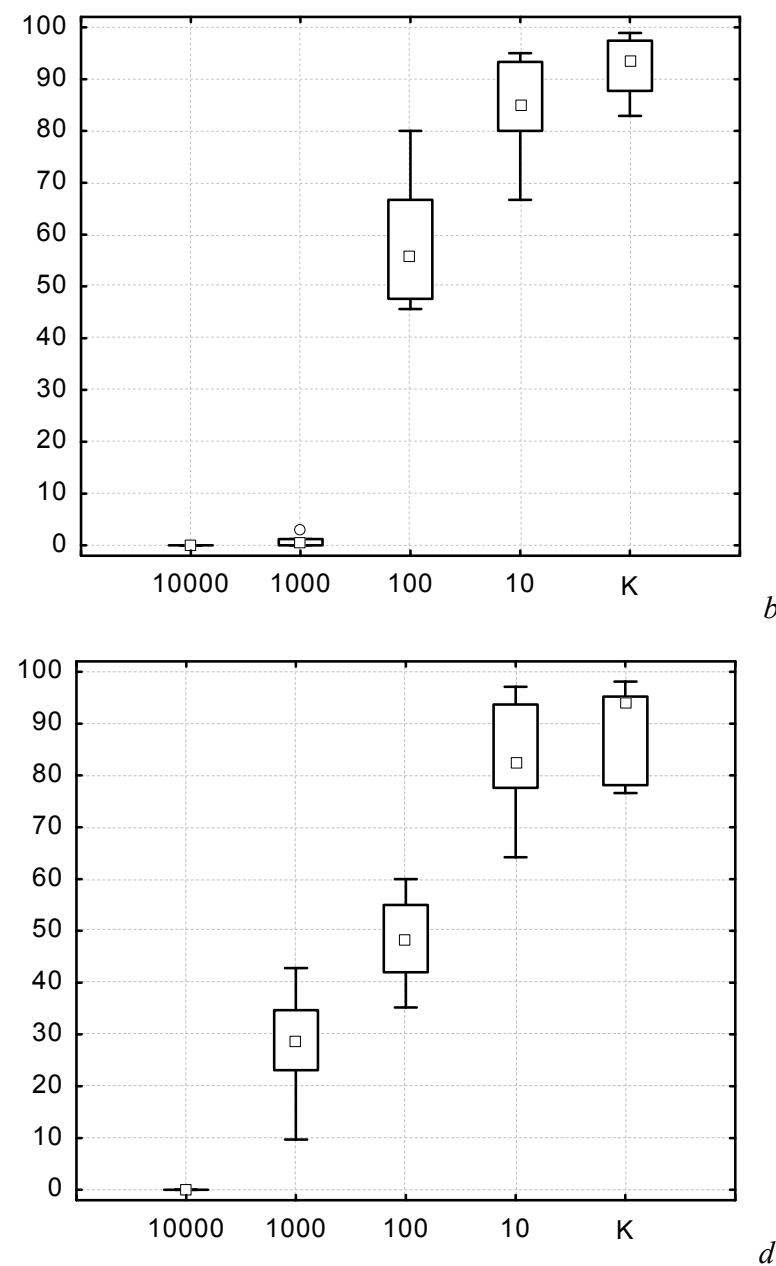

et al., 2008; Si et al., 2009; Belletti et al., 2010). Research on the effect of citral on infectious agents also supports the findings from our experiments on the viability of $S$. ransomi larvae. The effect of benzaldehyde and beta-ionone has been insufficiently studied.

For pest control in agriculture a number of authors have suggested using the food flavouring agent cinnamic aldehyde and also acaricidal substances (Knoblauch and Fry, 2011; Na et al., 2011; Shen et al., 2012; Belkind et al., 2013). According to Shen et al. (2012), after using this flavouring agent for 24 hours, $\mathrm{LD}_{50}$ for Psoroptes was $107 \mathrm{mg} / \mathrm{ml}$. Na et al. (2011) used it against Dermatophagoides of birds: $\mathrm{LD}_{50}$ after 24 hours was $0.54 \mathrm{mg} / \mathrm{ml}$. This substance was also tested by Cheng et al. (2009) against mosquito larvae: during 24 hours $\mathrm{LD}_{50}$ was $40.8 \mathrm{mg} / \mathrm{ml}\left(\mathrm{LD}_{90}=\right.$ $81.7 \mathrm{mg} / \mathrm{ml})$ and $46.5 \mathrm{mg} / \mathrm{ml}\left(\mathrm{LC}_{90}=83.3 \mathrm{mg} / \mathrm{ml}\right)$ for cinnamic aldehyde and cinnamic acetate, respectively. According to Lee et al. (2008), cinnamic aldehyde, benzaldehyde, linalool, limonene, alphaTerpineol and other flavouring agents have insecticidal properties against Sitophilus oryzae (Linnaeus, 1763) (Coleoptera, Curculionidae): $\mathrm{LD}_{50}$ at 48 hours exposure was $0.004-0.200 \mathrm{mg} / \mathrm{cm}^{2}$.

As a fungicidal substance it is advised to use $\mathrm{E}_{210}$ (Codex Alimentarius), or benzoic asid, which is also included in other food additives, such as $\mathrm{E}_{211}$ - Sodium Benzoate, $\mathrm{E}_{212}$ - Potassium Benzoate, $\mathrm{E}_{213}$ - Calcium dibenzoate (Beerse et al., 2001; Amborabe et al., 2002; Joshi et al., 2008)

Methylparabene is used against fungi, and also as an antiseptic (Shapiro et al., 2002; Posey et al., 2005; Kromidas et al., 2006; Rebbeck et al., 2006; Ishiwatari et al., 2007; Gopalakrishnan et al., 2012). This substance is also included as a preservative in an insecticide aimed at controlling agricultural pests (Bell, 1990).

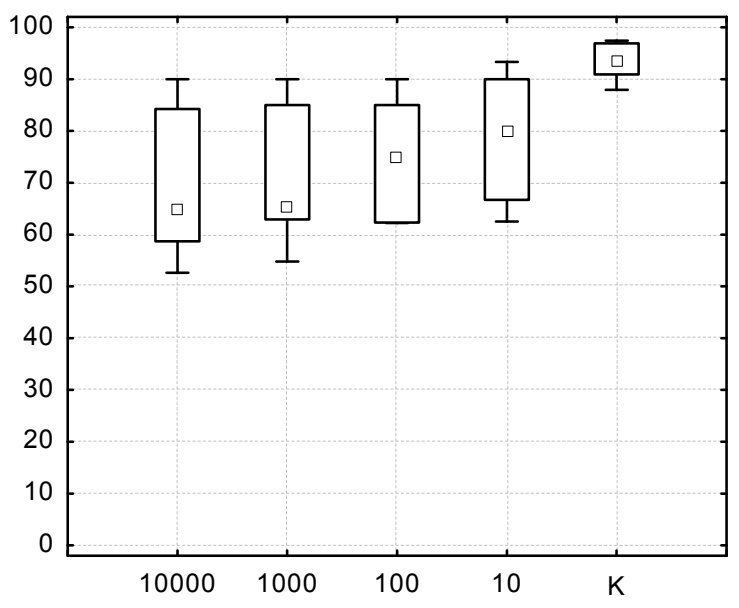

$b$

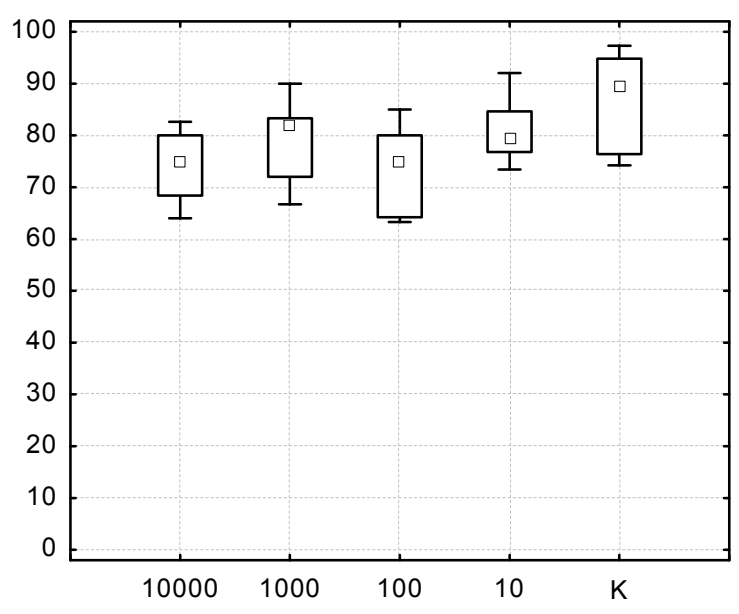

Fig. 2. The effect of benzaldehyde $(a)$, D-limonene $(b)$, citral $(c)$ and beta-ionone $(d)$ on the viability of $S$. ransomi larvae: along the axes of abscissa - variant of experiment ( $\mathrm{mg} / \mathrm{l})$, along the axes of ordinate - viability of $S$. ransomi larvae during 24 hours of laboratory experiment $(\%) ; n=8$ for each variant of experiment 
The flavouring agent benzaldehyde also shows insecticidal properties. The negative effect of benzaldehyde upon Galleria mellonella (Linnaeus, 1758) has been demonstrated. Therefore it is recommended for use in developing new agricultural insecticidal preparations (Ullah et al., 2015). The effect of beta-ionone upon living organisms has received insufficient study. Indeed, the effect of entire groups of flavouring agents upon living organisms requires further studyin general.

\section{Conclusions}

We researched the effect of flavouring agents such as benzaldehyde, citral, D-limonene and beta-ionone upon the viability of S. ransomi, parasitic larvae on pigs. We determined the minimum values of $\mathrm{LD}_{50}$ for benzaldehyde and citral. Experimentally, a death rate of $50 \%$ of the tested larvae was not achieved using D-limonene and beta-ionone. Food additives with a pleasant flower odour, which are permitted to be used for food, and which are used as cosmetics, are important for evaluating potential new antihelminthic medical and veterinary preparations.

\section{References}

Amborabe, B.-E., Fleurat-Lessard, P., Chollet, J. F., \& Roblin, G. (2002). Antifungal effects of salicylic acid and other benzoic acid derivatives towards Eutypa lata: Structure - activity relationship. Plant Physiology and Biochemistry, 40, 1051-1060.

Beerse, P. W., Biedermann, K. A., Page, S. H., Mobley, M. J., \& Morgan, J. M. (2001). Antimicrobial compositions comprising a benzoic acid analog and a metal salt. U.S. Patent No. 6294186. Lybertyville, IL, USA.

Belkind, B. A., Shammo, B., Dickenson, R., Rehberger, L. A., \& Heiman, D. F. (2013). Cinnamaldehyde and diallyl disulfide formulations and methods of use. U.S. Patent No. 20130018107. Libertyville, IL, USA.

Bell, M. (1990). Insecticidal aqueous-based microemulsion compositions. U.S. Patent No. 4904695. Stamford, CT, USA.

Belletti, N., Kamdem, S. S., Tabanelli, G., Lanciotti, R., \& Gardini, F. (2010). Modeling of combined effects of citral, linalool and $\beta$-pinene used against Saccharomyces cerevisiae in citrus-based beverages subjected to a mild heat treatment. International Journal of Food Microbiology, 136(3), 283-289.

Boyko, O. O., Zazharkka, N. M., \& Brygadyrenko, V. V. (2016). The influence of the extent of infestation by helminths upon changes in body weight of sheep in Ukraine. Visnyk of Dnipropetrovsk University. Biology, Ecology, 24(1), 3-7.

Burke, J. M., Wells, A., Casey, P., \& Kaplan, R. M. (2009). Herbal dewormer fails to control gastrointestinal nematodes in goats. Veterinary Parasitology, $160(1-2), 168-170$.

Charlier, J., Duchateau, L., Claerebout, E., Williams, D., \& Vercruysse, J. (2007). Associations between anti-Fasciola hepatica antibody levels in bulk-tank milk samples and production parameters in dairy herds. Preventive Veterinary Medicine, 78(1), 57-66.

Cheng, S.-S., Liu, J.-Y., Huang, C.-G., Hsui, Y.-R., Chen, W.-J., \& Chang, S.-T. (2009). Insecticidal activities of leaf essential oils from Cinnamomum osmophloeum against three mosquito species. Bioresource Technology, 100, 457-464.

Chiang, L.-C., Ng, L.-T., Cheng, P.-W., Chiang, W., \& Lin, C.-C. (2005). Antiviral activities of extracts and selected pure constituents of Ocimum basilicum. Clinical and Experimental Pharmacology and Physiology, 32(10), 811-816.

Cringoli, G., Veneziano, V., Jackson, F., Vercruysse, J., Greer, A. W., Fedele, V., Mezzino, L., \& Rinaldi, L. (2008). Effects of strategic anthelmintic treatments on the milk production of dairy sheep naturally infected by gastrointestinal strongyles. Veterinary Parasitology, 156(3-4), 340-345.

Eysker, M., Boerdam, G. A., Hollanders, W., \& Verheijden, J. H. M. (1994). The prevalence of Isospora suis and Strongyloides ransomi in suckling piglets in the Netherlands. Veterinary Quarterly, 16(4), 203-205.

Faye, D., Leak, S., Nouala, S., Fall, A., Losson, B., \& Geerts, S. (2003). Effects of gastrointestinal helminth infections and plane of nutrition on the health and productivity of F1 (West African Dwarf $\times$ Sahelian) goat crosses in The Gambia. Small Ruminant Research, 50(1-2), 153-161.

Gopalakrishnan, S., Chitra, T. A., Aruna, A., \& Chenthilnathan, A. (2012). Development of RP-HPLC method for the simultaneous estimation of ambroxol hydrochloride, cetirizine hydrochloride and antimicrobial preservatives in combined dosage form. Scholars Research Library, Der Pharma Chemica, 4(3), 1003-1015.
Ishiwatari, S., Suzuki, T., Hitomi, T., Yoshino, T., Matsukuma, S., \& Tsuji, T. (2007). Effects of methyl paraben on skin keratinocytes. Journal of Applied Toxicology, 27, 1-9.

Joshi, S. D., Vagdevi, H. M., Vaidya, V. P., \& Gadaginamath, G. S. (2008) Synthesis of new 4-pyrrol-1-yl benzoic acid hydrazide analogs and some derived oxadiazole, triazole and pyrrole ring systems: A novel class of potential antibacterial and antitubercular agents. European Journal of Medicinal Chemistry, 43, 1989-1996.

Knecht, D., Popiołek, M., \& Zaleśny, G. (2011). Does meatiness of pigs depend on the level of gastro-intestinal parasites infection? Preventive Veterinary Medicine, 99(2-4), 234-239.

Knoblauch, C., \& Fry, K. (2011). Non-toxic insecticide. U.S. Patent No. 7956092. Edmonton, Alberta, CA, USA.

Kromidas, L., Perrier, E., Flanagan, J., Rivero, R., \& Bonnet, I. (2006). Release of antimicrobial actives from microcapsules by the action of axillary bacteria. International Journal of Cosmetic Science, 28, 103-108.

Lee, E.-J., Kim, J.-R., Choi, D.-R., \& Ahn, Y.-J. (2008). Toxicity of cassia and cinnamon oil compounds and cinnamaldehyde-related compounds to Sitophilus oryzae (Coleoptera: Curculionidae). Journal of Economic Entomology, 101(6), 1960-1966.

Lu, C. D., Gangyi, X., \& Kawas, J. R. (2010). Organic goat production, processing and marketing: Opportunities, challenges and outlook. Small Ruminant Research, 89(2-3), 102-109.

Maslova, E. N., Sidorova, K. A., Antropov, V. A., \& Dragich, O. A. (2015). Otsenka tyazhesti techeniya bolezni pri parazitozakh svinej [Assessment of the severity of the disease in parasitic diseases of pigs]. Modern Problems of Science and Education, 3, 1-8 (in Russian).

Na, Y. E., Kim, S.-I., Bang, H.-S., Kim, B.-S., \& Ahn, Y.-J. (2011). Fumigant toxicity of cassia and cinnamon oils and cinnamaldehyde and structurally related compounds to Dermanyssus gallinae (Acari: Dermanyssidae). Veterinary Parasitology, 178, 324-329.

Ponamar, S. I., Shendrik, L. I., Shendrik, C. M., Gugosyan, Y. A., \& Shendrik, I. M. (2014a). Izmenenie gematologicheskikh pokazatelej do i posle lecheniya telyat pri strongiloidoze [Changes in hematology parameters before and after treatment of calves reached strongyloidiasis]. Science and Technology Bulletin of Scientific Research Center for Biosafety and Environmental Control of Agro-Industrial Complex, 2(2), 112-118 (in Ukrainian).

Ponomar, S. I., Goncharenko, V. P., Kruchinenko, O. V., \& Shendrik, C. N. (2014b). Ehffektivnost' kompleksnogo podkhoda pri postanovke diagnoza na strongiloidoz [Effectiveness of the integrated approach in the diagnosis of strongyloidiasis]. Scientific Messenger of Veterinary Medicine, 13, 190-193 (in Ukrainian).

Ponomar, S. I., Soroka, N. M., \& Ponomar, Z. S. (2013). Kompleksnaya ehtiotropnaya terapiya svinej pri nematodozakh [Complex ethiotropic therapy for pigs infected by nematodoses]. Veterinary, 2, 29-31 (in Russian).

Posey, R., Culbertson, E. C., \& Westermeier, J. C. (2005). Clear barrier coating and coated film. U.S. Patent No. 6911255. Greer, SC, USA.

Rahmann, G., \& Seip, H. (2006). Alternative strategies to prevent and control endoparasite diseases in organic sheep and goat farming systems. Ressortforschung für den Ökologischen Landbau, 298, 49-90.

Rebbeck, C., Hammond, R., Wong, J., Nair, L., \& Raghavan, N. (2006). Solidphase extraction and HPLC analysis of methylparaben and propylparaben in a concentrated antibiotic suspension. Drug Development and Industrial Pharmacy, 32, 1095-1102.

Samsonovich, V. A. (2012a). Ehkologicheskie osobennosti ehpizootologii strongiloidoza porosyat [Ecological features of epizootology strongyloidosis pigs]. Scientific Notes of the Bauman Kazan State Academy of Veterinary Medicine, 211, 135-138 (in Russian).

Samsonovich, V. A. (2012b). Vliyanie strongiloidov na morfologicheskij sostav krovi i pokazateli estestvennoj rezistentnosti u porosyat [Influence of Strongyloides on the morphological composition of the blood and indicators of natural resistance in pigs]. Proceedings of the National Academy of Sciences of Belarus. Series of Agrarian Sciences, 3, 74-79 (in Russian).

Sato, K., Krist, S., \& Buchbauer, G. (2006). Antimicrobial effect of transCinnamaldehyde, (-)-Perillaldehyde, (-)-Citronellal, Citral, Eugenol and Carvacrol on airborne microbes using an airwasher. Biological and Pharmaceutical Bulletin, 29(11), 2292-2294.

Shapiro, S., Giertsen, E., Guggenheim, B. (2002). An in vitro oral biofilm model for comparing the efficacy of antimicrobial mouthrinses. Caries Research, 36, 93-100.

Shen, F., Xing, M., Liu, L., Tang, X., Wang, W., Wang, X., Wu, X., Wang, X., Wang, X., Wang, G., Zhang, J., Li, L., Zhang, J., \& Yu, L. (2012). Efficacy of trans-cinnamaldehyde against Psoroptes cuniculi in vitro. Parasitology Research, 110, 1321-1326.

Si, W., Ni, X., Gong, J., Yu, H., Tsao, R., Han, Y., \& Chambers, J. R. (2009). Antimicrobial activity of essential oils and structurally related synthetic food additives towards Clostridium perfringens. Journal of Applied Microbiology, 106(1), 213-220. 
Smirnov, E. V. (2008). Pishhevye aromatizatory [Food flavors]. Profession, Saint Petersburg (in Russian).

Somolinos, M., Garcia, D., Pagan, R., \& Mackey, B. (2008). Relationship between sublethal injury and microbial inactivation by the combination of high hydrostatic pressure and citral or tert-butyl hydroquinone. Applied and Environmental Microbiology, 74(24), 7570-7577.

Sun, J. (2007). D-Limonene: Safety and clinical applications. Alternative Medicine Review, 12(3), 259-264.

Ullah, I., Latif, A. K., Ali, L., Khan, A. R., Waqas, M., Hussain, J., Lee, I.-J., \& Shin, J.-H. (2015). Benzaldehyde as an insecticidal, antimicrobial, and antioxidant compound produced by Photorhabdus temperata. Journal of Microbiology, 53(2), 127-133.
Van Wyk, J. A., \& Mayhew, E. (2013). Morphological identification of parasitic nematode infective larvae of small ruminants and cattle: A practical lab guide. Onderstepoort Journal of Veterinary Research, 80(1), 1-14.

Veneziano, V., Rubino, R., Fedele, V., Rinaldi, L., Santaniello, M., Schioppi, M., Cascone, C., Pizzillo, M., \& Cringoli, G. (2004). The effects of five anthelmintic treatment regimes on milk production in goats naturally infected by gastrointestinal nematodes. South African Journal of Animal Science, 34, 238-240.

Yamov, V. Z., \& Antropov, V. A. (2008). Ehpizootologiya gel'mintozov svinej na tyumenskom yuge [Epizootology of pigs helminthosis in the south of Tyumen]. Agricultural Messenger of Ural Veterinary Science, 47, 70-71 (in Russian).

Zajac, A. M., \& Conboy, G. A. (eds.) (2011). Veterinary clinical parasitology, 8th ed. John Wiley and Sons, UK. 